\title{
The genetics of streaked and unstreaked morphs of the snails Achatina sylvatica Putzeys and Limicolaria cailliaudi (Pfeiffer)
}

\author{
John A. Allen
}

Department of Biology, University of Southampton, Southampton SO9 3TU, UK.

\begin{abstract}
The achatinid land snails Limicolaria cailliaudi and Achatina sylvatica are polymorphic for presence and absence of streaks on their shells. Thirty separate pairs of $L$. cailliaudi and twenty of $\boldsymbol{A}$. sylvatica were reared to maturity in captivity. Six crosses of $\boldsymbol{L}$. cailliaudi and four of $\boldsymbol{A}$. sylvatica produced progeny and in both species the morphs segregated in a manner that suggests that absence of streaks is controlled by an allele recessive to one for their presence.
\end{abstract}

The markings on the shells of achatinid land snails are in the form of streaks that run across the whorls, and, in common with many other pulmonates, these snails are often polymorphic for shell colour and pattern. A particularly widespread polymorphism is that for the presence or absence of streaks (Bequaert (1950); Crowley and Pain (1970)). In all four species so far examined, absence of streaks appears to be controlled by an allele recessive to one for their presence: Limicolaria flammulata (Pfeiffer) and L. aurora (Jay), Barker $(1968,1969)$; L. martensiana (Smith), Allen (in preparation); and Achatina fulica Bowdich, Allen (1983). I now present data which suggest that recessive genes control the absence of streaks in $L$. cailliaudi (Pfeiffer) and $A$. sylvatica Putzeys.

In May 1974, Mr Rim Kwa Chanzu collected twelve live specimens of $L$. cailliaudi from thickets on the south-east slopes of Mount Elgon, Kenya (altitude 2000-2500 metres above sea level). Seven snails were streaked and five were unstreaked. The ground colour, a light straw-yellow, appeared to be the same in both morphs. The snails were reared separately in soil-filled plastic beer pots in the author's office in the Department of Zoology, University of Dar es Salaam, Tanzania, using the methods described for A. fulica (Allen, 1983). Four snails laid batches of eggs. Each batch was transferred to a separate pot and when the hatchlings were 1-2 months old (and presumably still virgin) they were housed in pairs in thirty fresh pots. Only six of the crosses produced offspring. Each brood was reared in a single large pot and the morphs were scored when the snails were 2-3 months old.

Pilsbry (1919, pp. 67-68) describes the streaked and unstreaked ("mutation" unicolor) forms of $\boldsymbol{A}$. sylvatica from Kisangani (Stanleyville), Zaire. My material was also obtained from Kisangani. In late 1975, Mr George Millikan collected six live snails ( 3 streaked and 3 unstreaked) from a papaya tree (Carica papaya) on cultivated land in the town. Both morphs had a pale yellow ground colour. The snails were placed singly in disposable plastic tea-cups half-filled with moist soil and kept in a constant temperature room $\left(25^{\circ}\right)$ in the Department of Zoology, University of Reading, U.K. Within two months three of the pots contained hatchlings. When these were about two months old they were reared in pairs in fresh cups and were maintained in the same way as the pairs of L. cailliaudi. Four of the twenty crosses produced offspring, which were scored when the snails were about two months old.

The paucity of results (tables 1 and 2) suggests that these two species were more difficult to breed than A. fulica and L. martensiana (Allen, 1983 and unpublished). Nevertheless, the morphs clearly segregated in the progeny, implying that the variation in both species is under genetic control. For L. cailliaudi (table 1), crosses 14 and 27 provide the best evidence that the unstreaked form is deter- 
Table 1 Results of breeding experiments with $L$. cailliaudi. The two sites were $40 \mathrm{~km}$ apart on the south-eastern slopes of Mt. Elgon, Kenya

\begin{tabular}{|c|c|c|c|c|}
\hline \multirow{3}{*}{$\begin{array}{l}\text { Cross no. } \\
2\end{array}$} & \multirow{3}{*}{$\begin{array}{l}\text { Provenance } \\
\text { Kimilili } \\
\text { Kimilili }\end{array}$} & \multirow{3}{*}{$\begin{array}{l}\text { Parents } \\
\left.\begin{array}{l}\text { streaked } \\
\text { streaked }\end{array}\right\}\end{array}$} & \multicolumn{2}{|c|}{ Progeny } \\
\hline & & & $\begin{array}{l}\text { Nos. of } \\
\text { streaked }\end{array}$ & $\begin{array}{l}\text { Nos. of } \\
\text { unstreaked }\end{array}$ \\
\hline & & & 7 & 0 \\
\hline 4 & $\begin{array}{l}\text { Kimilili } \\
\text { Kimilili }\end{array}$ & $\left.\begin{array}{l}\text { streaked } \\
\text { unstreaked }\end{array}\right\}$ & 3 & 0 \\
\hline 13 & $\begin{array}{l}\text { Kimilili } \\
\text { Malava }\end{array}$ & $\left.\begin{array}{l}\text { unstreaked } \\
\text { unstreaked }\end{array}\right\}$ & 0 & 7 \\
\hline 14 & $\begin{array}{l}\text { Kimilili } \\
\text { Malava }\end{array}$ & $\left.\begin{array}{l}\text { streaked } \\
\text { streaked }\end{array}\right\}$ & 9 & 2 \\
\hline 16 & $\begin{array}{l}\text { Malava } \\
\text { Malava }\end{array}$ & $\left.\begin{array}{l}\text { streaked } \\
\text { streaked }\end{array}\right\}$ & 13 & 0 \\
\hline 27 & $\begin{array}{l}\text { Malava } \\
\text { Malava }\end{array}$ & $\left.\begin{array}{l}\text { streaked } \\
\text { streaked }\end{array}\right\}$ & 19 & 9 \\
\hline
\end{tabular}

Table 2 Results of breeding experiments with $A$. sylvatica. All the parents were from a single site in Kisangani, Zaire

\begin{tabular}{llll}
\hline Cross no. & Parents & \multicolumn{2}{c}{ Progeny } \\
\hline & & $\begin{array}{l}\text { Nos. of } \\
\text { streaked }\end{array}$ & $\begin{array}{l}\text { Nos. of } \\
\text { unstreaked }\end{array}$ \\
1 & streaked $\times$ unstreaked & 6 & 8 \\
9 & streaked $\times$ unstreaked & 11 & 0 \\
16 & streaked $\times$ streaked & 23 & 0 \\
20 & streaked $\times$ streaked & 2 & 0 \\
\hline
\end{tabular}

mined by a recessive allele. The proportions of the morphs in the two sets of progeny do not differ significantly from one another $(p=0.33$, Fisher's Exact Test). Pooling the data from the two crosses, there is no significant deviation from a $3: 1$ ratio expected from a mating between two heterozygotes $\left(\chi_{(1)}^{2}=0 \cdot 27\right)$. A genetic control of streaking in $A$. sylvatica is supported by the results from cross 1 (table 2), which fit a $1: 1$ ratio expected from a backcross $(p=0 \cdot 44$, Binomial test $)$. Evidence for the dominant nature of the allele for streaking is given by cross 9 , the results of which depart significantly from a $1: 1$ ratio expected from a backcross $(p<0.001$, Binomial test $)$ and fit the expectation from a cross between a snail homozygous for the dominant allele for presence of streaks and a snail homozygous for the recessive allele for absence of streaks.

The unstreaked morphs of $L$. cailliaudi and A. sylvatica hence seem to be determined by recessive alleles and the genetic basis of streaking now appears to be the same in six species of achatinid land snail. This might reflect the apparent generality that the alleles controlling the presence of shell markings in pulmonate snails are usually dominant to those controlling the absence of markings (Murray, 1975; Clarke et al., 1978).

Acknowledgements The author gratefully acknowledges the assistance provided by the Department of Zoology, University of Dar es Salaam, the Department of Zoology, University of Reading and the Department of Biology, University of Southampton. Mr T. E. Crowley confirmed the identification of the two species and a referee made helpful comments on the manuscript.

\section{REFERENCES}

ALLEN, J. A. 1983. The inheritance of a shell colour polymorphism in Achatina fulica Bowdich from East Africa. J. Conch., $3 l, 185-189$.

BARKER, J. F. 1968. Polymorphism in West African snails. Heredity, 23, 81-96.

BARKER, J. F. 1969. Polymorphism in a West African snail. Am. Nat., 103, 259-266. 
BequaERT, J. C. 1950. Studies in the Achatininae, a group of African land snails. Bull. Mus. comp. Zool. Harv., 105, $1-216$.

ClARKE, B. C., ARTHUR, W., HORSLEY, D. T. AND PARKIN, D. T. 1978. Genetic variation and natural selection in pulmonate molluscs. In: The pulmonates, Vol. 2A, (eds) V. Fretter and J. Peake. Academic Press, New York and London.
CROWLEY, T. E. AND PAIN, T. 1970. A monographic revision of the African land snails of the genus Limicolaria Schumacher (Mollusca-Achatinidae). Annls. Mus. r. Afr. cent. Ser. 8 vo (Sci. Zoologiques), 177, 1-61.

MURRAY, J. 1975. The genetics of the mollusca. In: Handbook of Genetics, vol. 3, (ed.) J. C. King. Academic Press, New York and London.

PILSBRY, H. A. 1919. A review of the land mollusks of the Belgian Congo. Bull. Am. Mus. Nat. Hist., 40, 1-370. 